\title{
Note on the undulatory theory of light
}

\section{John Tovey Esq.}

To cite this article: John Tovey Esq. (1839) Note on the undulatory theory of light, Philosophical Magazine Series 3, 14:91, 479-479, DOI: 10.1080/14786443908649797

To link to this article: http://dx.doi.org/10.1080/14786443908649797

册 Published online: 01 Jun 2009.

Submit your article to this journal 준

Џll Article views: 3

Q View related articles $₫$ 
The value of the dip is the mean of the three following amounts, $68^{\circ} 22^{\prime}, 25,68^{\circ} 22^{\prime}, 67$, and $68^{\circ} 22^{\prime}, 25$, obtained in succession on the 3 Ist of March. These observations were made under very favourable circumstances. As in preceding years, it was thought proper tc make the different observations for the declination and the dip at the same time of year and about the same hours of the day.

\section{NOTE ON THE UNDULATORY THEORY OF LIGHT.}

BY JOHN TOVEY, ESQ.

To the Editors of the Philosophical Magazine.

Gentumen,

I perceive that the formula (18) of my paper in your present vol., p. 171, appear to lead to contradictory results; I shall be glad, therefore, if you will allow me to say, that this matter will be cleared up in my next paper, which will contain an improved method of finding the general integrals.

Littlemoor, Clitheroe, May 13th, 1839.

I am, Gentlemen, yours, \&c., JoHN TOVEY.

METEOROLOGICAL OBSERVATIONS FOR APRIL, 1839.

Chiswick.-A pril 1. Rain. 2. Overcast. 8, 4. Bleak and cold. 5. Snowing. 6. Cloudy and cold. 7. Fine. 8. Snowing. 9. Bleak and cold. 10, 11. Fine but cold. 12-14. Cloudy and cold. 15. Overcast. 16. Very fine. 17. Showery. 18. Boisterous with rain. 19. Very fine. 20. Showery. 21. Fine. 22. Very fine. 23. Rain. 24-26. Fine. 27. Dry haze. 28-30. Very fine.

Boston.-A pril 1. Fine. 2. Stormy. 3-7. Cloudy. 8. Clpudy : sleet early A.M. 9. Cloudy, 10. Fine. 11-15. Cloudy. 16. Fine. 17, 18. Rain. 19. Fine : rain early A.M. 20, 21 . Fine: rain A.M. and P.M. 22. Fine: rain early A.M. 23. Rain. 24-26. Cloudy. 27. Cloudy : rain A.M. 28-30. Fine.

Applegarlh Manse, Dumfries-shire--April 1. A most inclement day : snow on hills. 2. The same: snow on hills meling. 3. The same: bitterly cold. 4. Another piercing day : cloudy P.M. 5. Still extremely cold : snow showers. 6. Wind fallen : more temperate. 7. Moderate day : still no vegetation. 8. Piercingly cold and withering. 9. Dry and cold: frosty mornings. 10. Sun warm, but wind cold and withering. 11. Milder, but still no spring. 12. Great increase of temperature. 13, Sun warm: wind moderate but parching. 14. Moderate day : vegetation commencing. 15. The same: temperature lower: cloudy. 16. Threatening rain : showery : very wet P.M. 17. Showers: rain : hail : cleared P.M. 18. Frequent showers : rain and sleet : snow. 19. Violent wind : showers of hail. 20. Dry and cold : vegetation at a stand. 21. Dry : temperature rising. 22. Foggy morning : drizzling day. 23. Clear: temperature increasing. 24. The same : cool evening. 25. Temperature increasing : clear sun. 26. Cloudy : threatening cleared up P. M. 27. Clear and fine : hoar frost morning. 28. The same: cloudy r.M. 29. Fine spring day. 30. Remarkably fine spring day.

Sun 25 days. Rain 4 days. Snow 2 days. Hail 2 days. Frost 3 mornings. days.

Wind easterly 13 days. Southerly 12 days. Northerly 2 days. Westerly $\mathrm{S}$

Calm 11 days. Moderate 7 days. Strong breeze 4 days. Stormy 5 days.

Brisk 3 days.

Mean daily ange of harometer 0.092 . Mean nightly range 0.080 . Mean range of 24 hours $0 \cdot 172$.

Mean daily range of thermometer $10^{\circ} 4$. 